\title{
Author Correction: Global warming hiatus contributed weakening of the Mascarene High in the Southern Indian Ocean
}

\author{
Vidya P. J., M. Ravichandran, M. P. Subeesh, Sourav Chatterjee \& Nuncio M. \\ Correction to: Scientific Reports https://doi.org/10.1038/s41598-020-59964-7, published online 24 February 2020 \\ This Article contains a typographical error in the Supplementary Information file where the title, \\ "Weakening of the Mascarene High and its implication to the cross-equatorial winds in the western Indian \\ Ocean" \\ should read: \\ "Global warming hiatus contributed weakening of the Mascarene High in the Southern Indian Ocean" \\ Additionally, in the Acknowledgements section, \\ “The authors thank Ms Jyoti Jadav, IITM Pune for helpful discussions." \\ should read: \\ “The authors thank Ms Jyoti Jadhav, IITM Pune for helpful discussions."
}

(c) (i) Open Access This article is licensed under a Creative Commons Attribution 4.0 International License, which permits use, sharing, adaptation, distribution and reproduction in any medium or format, as long as you give appropriate credit to the original author(s) and the source, provide a link to the Creative Commons license, and indicate if changes were made. The images or other third party material in this article are included in the article's Creative Commons license, unless indicated otherwise in a credit line to the material. If material is not included in the article's Creative Commons license and your intended use is not permitted by statutory regulation or exceeds the permitted use, you will need to obtain permission directly from the copyright holder. To view a copy of this license, visit http://creativecommons.org/licenses/by/4.0/.

(C) The Author(s) 2020 